\title{
The activity of saccharolytic enzymes in Collembola is associated with species affinity for caves
}

\author{
Andrea Parimuchová ${ }^{1^{*}}$, Vladimír Šustr ${ }^{2,6}$, Miloslav Devetter $^{2,3}$, Ondřej Vošta ${ }^{4}$, \\ Ionuț Popa ${ }^{5}$, and L'ubomír Kováč ${ }^{1}$ \\ ${ }^{1}$ Department of Zoology, Institute of Biology and Ecology, Faculty of Science, P. J. Šafárik University, Moyzesova 11 , 04154 Košice, Slovakia \\ ${ }^{2}$ Institute of Soil Biology, Biology Centre AS CR v. v. i., Na Sádkách 7, 37005 České Budějovice, Czech Republic \\ ${ }^{3}$ Centre for Polar Ecology, University of South Bohemia, Na Zlaté Stoce 3, 37005 České Budějovice, Czech Republic \\ ${ }^{4}$ Czech-English Grammar School, Třebízského 1010, 37005 České Budějovice, Czech Republic \\ ${ }^{5}$ Department of Biospeleology and Karst Edaphobiology, Institute of Speleology "Emil Racoviță", Frumoasă 31, 010986 Bucharest, Romania \\ ${ }^{6}$ SOWA Research infrastructure, Biology Centre AS CR v. v. i., Na Sádkách 7, 37005 České Budějovice, Czech Republic
}

\begin{abstract}
The activity of enzymes associated with digestion can reflect food availability and feeding preferences of invertebrates in a particular habitat. Caves are mostly nutrient-poor habitats lacking primary production. In the present study the enzymatic activity of cellulases, trehalases and chitinases was measured in eight collembolan species differently associated with the cave environment: the troglobionts (obligate cave species) Pseudacherontides spelaeus and Protaphorura janosik; the eutroglophiles Ceratophysella denticulata, Folsomia candida and Heteromurus nitidus; the subtroglophiles Hypogastrura aequepilosa and Orthonychiurus rectopapillatus; and the trogloxene (not associated with caves) Megaphorura arctica. Qualitative enzymatic patterns and quantitative differences in species activity were considered in terms of the taxonomic, feeding and ecological classifications of Collembola. Activity of the tested enzymes was confirmed in all species. Cellulolytic and chitinolytic activity seemed to play a crucial role for the discrimination of guilds within all categories. An increasing trend of chitinolytic activity was observed in Collembola associated with the subterranean environment and deeper soil layers, while cellulolytic activity decreased towards more adapted cave forms. Variability in enzymatic activity in cave-dwelling species indicated food specialization across sub- and eutroglophiles and troglobionts, respectively. The results of this study point out that enzymatic activity varies between groups of the cave fauna with different degrees of association to subterranean habitats (cave guilds).
\end{abstract}

Keywords: enzymatic activity, cellulase, trehalase, chitinase, Collembola, cave guild

Received 7 September 2017; Revised 16 March 2018; Accepted 28 March 2018

Citation: Parimuchová A., Šustr V., Devetter M., Vošta O., Popa I. and Kováč L., 2018. The activity of saccharolytic enzymes in Collembola is associated with species affinity for caves. International Journal of Speleology, 47 (2), 155-163. Tampa, FL (USA) ISSN 0392-6672 https://doi.org/10.5038/1827-806X.47.2.2150

\section{INTRODUCTION}

Feeding ecology among soil Collembola reflects the high heterogeneity of the soil environment (Chahartaghi et al., 2005). Collembola are generally classified as decomposers (Rusek, 1998), feeding unselectively on a wide variety of food materials. However, the trophic niches of species vary among different collembolan orders and families, indicating a pronounced phylogenetic signal that supports the trophic-niche conservativism hypothesis (Potapov et al., 2016).

Food resources in caves are depleted when compared with surface ecosystems, which obtain energy and organic carbon from photosynthesis by green plants. Microbial communities represent the base of the food pyramid in caves (Camassa, 2004), and they rely almost entirely on surface organic resources actively or passively transported into the caves. The most available food sources in caves are animal cadavers, faeces, animal eggs and plant debris (leaf litter, rotten wood). Generally, Collembola that occupy environments with both plant and fungal food sources available are able to alternate herbivory and fungivory (Endlweber et al., 2009).

While collembolan communities diverge vertically in above-ground ecosystems, their horizontal distribution is distinct in caves. Trogloxenes and subtroglophiles are abundant in entrance zones illuminated during the day (euphotic zone) and characterized by the 
presence of algae, bryophytes and phanerogams, while eutroglophiles and troglobionts live permanently in an environment devoid of fresh plant food sources (Culver and Pipan, 2009; Kováč et al., 2014).

Food composition in Collembola has been studied using various techniques, such as analyses of gut content (e.g. Ponge, 2000; Castaño-Meneses et al., 2004; Fiera, 2014), activity of digestive enzymes (Zinkler, 1971; Urbášek \& Rusek, 1994; Berg, 2004), lipid composition (Ruess et al., 2007) or stable isotopes (e.g. Ruess et al., 2004; Chahartaghia et al., 2005; Endlweber et al., 2009; Potapov et al., 2016). Each method has its own limitations, and a combination of several approaches seems to be the proper way to better understand feeding ecology and to refine the functional ecological classification of soil mesofauna.

Regarding the usual interpretation of digestive enzymes, the presence of cellulase activity in the digestive tract of an animal suggests the ability to digest algae and plant materials and indicates herbivory. On the other hand, the presence of trehalase activity indicates the ability to digest the cell contents but not the cell walls of lichens and microbes, while chitinases enable digestion of the hyphae contents and cell walls of fungi (Siepel \& De Ruiter-Dijkman, 1993; Berg et al., 2004). Along with digestion, potential non-digestive roles of enzymes also appear. Invertebrate chitinases can subserve arthropod molting (Merzendorfer \& Zimoch 2003), defense/immunity and pathogenicity (Arakane \& Muthukrishnan, 2010). Trehalose is a haemolymph transport sugar of insects having a role in the regulation of food intake and stress protection (Thompson, 2003). In Collembola, trehalose has an important role as a cryoprotective agent as well (Sinclair \& Sjursen, 2001), and its activity can vary seasonally, especially in arctic species.

Moreover, an association is assumed between the specific enzymatic activity of Collembola and their vertical stratification in the soil profile (life form) (Urbášek \& Rusek, 1994). Vertical migration induced by seasonal changes in habitats and subsequent seasonal alternation of food sources is common in some collembolan species (e.g. Hishi et al., 2007).

The level of enzymatic activity depends on the type of food consumed prior to sampling and phase of the life cycle (Berg et al., 2004). Moreover, the activity of some enzymes may significantly differ in the same species at two different sites (Berg et al., 2004).

The high morphological and ecological heterogeneity of Collembola has resulted in the proposal of different types of ecological classifications. The traditional classification of life forms is based on the general body plan (Gisin, 1943; Rusek, 2007), while enzymatic activity and the stable isotope ratio have been considered in more recent studies (Berg et al., 2004; Potapov et al., 2016). Based on qualitative differences in enzymatic equipment, several functional groups were defined in soil mesofauna (Siepel \& DeRuiterDijkman, 1993), representing functional variability within the group. Berg et al. (2004) found qualitative differences in cellulolytic, trehalolytic and chitinolytic equipment between collembolan species and sorted them into 4-5 principal feeding guilds (Siepel \& DeRuiter-Dijkman, 1993).

It is expected that enzymatic equipment may also differ considerably between cave-dwelling animals, depending on their nutritional ecology, but these studies have not been conducted yet.

The present study is one of the first attempts aimed at analyzing enzymatic activity in subterranean arthropods, specifically qualitative and quantitative differences in the activity of trehalase, cellulase and chitinases between Collembola with different affinity to the cave environment (cave guilds). We hypothesized that non-cave-adapted species living in an environment with more heterogenous food sources would have higher activity of some enzymes, especially cellulase, compared to obligate cave species.

\section{MATERIALS AND METHODS}

\section{Tested species and categorical variables}

Specimens were collected in the field together with substrate and organic material from collection sites and transported to the laboratory (Table 1). Seven collembolan species with various affinity to cave habitats were examined: Ceratophysella denticulata, Folsomia candida, Heteromurus nitidus, Hypogastrura aequepilosa, Orthonychiurus rectopapillatus, Protaphorura janosik and Pseudacherontides spelaeus. For comparison, Megaphorura arctica was tested as an example of a species that does not have any association with the cave environment; therefore, we consider it as "trogloxene". For practical purposes, we use the term "cave guild" to designate groups of species with different affinities to the cave environment, namely trogloxenes, subtroglophiles, eutroglophiles and troglobionts (Sket, 2008). Soil life forms after Rusek (2007) and feeding guilds after Potapov et al. (2016) were used as other categorical variables to reveal potential trophic niche specialization. Body length, number of eyes and total protein content were used as functional traits, with the body weight as a covariable.

\section{Evaluation of enzymatic activity}

Cellulase, trehalase and chitinase (glucosaminidase, chitobiase, endo-chitinase) activity was measured in eight collembolan species (see above). From 8 to 15 individuals of each species were weighed and washed with $0.6 \%$ cholic acid. Each group of collembolans was placed into a small glass mortar filled with $0.25 \mathrm{ml}$ of Britton-Robinson (BR) buffer $(\mathrm{pH}=6)$ and pulverised with a glass pestle until no body parts were recognizable. The mixture was transferred to a plastic Eppendorf tube placed in crushed ice. The mortar and pestle were rinsed with $0.25 \mathrm{ml}$ of BR buffer, and this volume was added to the Eppendorf tube. The homogenate was centrifugated at 6,000 rpm/7 min., and the supernatant was stored at $-18^{\circ} \mathrm{C}$ until used for enzyme activity assay. The activity of each enzyme was measured in 4-6 replications. In P. janosik, enzymatic activity in specimens from laboratory culture was compared with those collected in the field and pulverised immediately after transporting to the laboratory. 
Table 1. Collembola species and their life forms (LF) after Rusek (2007), cave forms (CF) after Sket (2008) and feeding guilds (FG) after Potapov et al. (2016).

\begin{tabular}{|c|c|c|c|c|c|c|c|c|c|c|}
\hline Species & Abb. & Family & LF & $\mathbf{C F}$ & FG & b1 & $\mathbf{s}$ & FH & Original locality & RC \\
\hline $\begin{array}{l}\text { Ceratophysella denticulata } \\
\text { (Bagnall, 1941) }\end{array}$ & Cde & Hypogastruridae & $\mathrm{Bb} 1$ & EU & EPAM & 1.8 & $\mathrm{~L}$ & A & $\begin{array}{c}\text { Čertova diera Cave } \\
\text { (SK) }\end{array}$ & $\mathrm{s}, \mathrm{y}$ \\
\hline $\begin{array}{l}\text { Folsomia candida } \\
\text { (Willem, 1902) }\end{array}$ & Fca & Isotomidae & $\mathrm{Bc} 2 \mathrm{a}$ & EU & HEM & 1.7 & $\mathrm{~L}$ & A & Domica Cave (SK) & s, y \\
\hline $\begin{array}{l}\text { Heteromurus nitidus } \\
\text { (Templeton, 1835) }\end{array}$ & $H n i$ & Entomobryidae & $\mathrm{Bc} 1 \mathrm{a}$ & $\mathrm{EU}$ & HEM & 3.0 & $\mathrm{~L}$ & A & Domica Cave (SK) & s, y \\
\hline $\begin{array}{l}\text { Hypogastrura aequepilosa } \\
\text { (Stach, 1949) }\end{array}$ & Haq & Hypogastruridae & $\mathrm{Bb} 1$ & SUB & EPAM & 2.0 & $\mathrm{~L}$ & A & $\begin{array}{c}\text { Čertova diera Cave } \\
\text { (SK) }\end{array}$ & s, y \\
\hline $\begin{array}{l}\text { Megaphorura arctica } \\
\text { Tullberg, } 1876\end{array}$ & Mar & Onychiuridae & $\mathrm{Bc} 1 \mathrm{~b}$ & $\mathrm{TX}$ & EPPM & 3.5 & $\mathrm{~L}$ & $\mathrm{~N}$ & $\begin{array}{l}\text { Svalbard, soil, } \\
\text { moss under bird } \\
\text { cliffs (N) }\end{array}$ & $\mathrm{s},-$ \\
\hline $\begin{array}{l}\text { Orthonychiurus rectopapillatus } \\
\text { (Stach, 1933) }\end{array}$ & Ore & Onychiuridae & $\mathrm{Bc} 1 \mathrm{~b}$ & SUB & EUM & 1.3 & $\mathrm{~L}$ & A & Domica Cave (SK) & $\mathrm{s}, \mathrm{y}$ \\
\hline $\begin{array}{l}\text { Protaphorura janosik } \\
\text { Weiner, } 1990\end{array}$ & Pja & Onychiuridae & $\mathrm{Bc} 1 \mathrm{~b}$ & TGB & EUM & 3.8 & $\mathrm{~F}$ & $\mathrm{~N}$ & $\begin{array}{l}\text { Jaskyña pod } \\
\text { Spišskou Cave } \\
\text { (SK) }\end{array}$ & - \\
\hline $\begin{array}{l}\text { Protaphorura janosik } \\
\text { Weiner, } 1990\end{array}$ & Pja2 & Onychiuridae & $\mathrm{Bc} 1 \mathrm{~b}$ & TGB & EUM & 3.8 & L & A & $\begin{array}{l}\text { Jaskyña pod } \\
\text { Spišskou Cave } \\
\text { (SK) }\end{array}$ & s, y \\
\hline $\begin{array}{l}\text { Protaphorura janosik } \\
\text { Weiner, } 1990\end{array}$ & Pja4 & Onychiuridae & $\mathrm{Bc} 1 \mathrm{~b}$ & TGB & EUM & 3.8 & $\mathrm{~F}$ & $\mathrm{~N}$ & Duča Cave (SK) & - \\
\hline $\begin{array}{l}\text { Pseudacherontides spelaeus } \\
\text { (Ionesco, 1922) }\end{array}$ & $P s p$ & Hypogastruridae & $\mathrm{Bc} 2 \mathrm{~b}$ & TGB & EUM & 0.7 & L & $\mathrm{N}$ & $\begin{array}{l}\text { Fânațe Cave (RO), } \\
\text { guano }\end{array}$ & $\mathrm{g},-$ \\
\hline
\end{tabular}

Codes: bl - body length (mm) (literature data); S - sample: L - laboratory, F - field; FH - food history: A - artificial (inactivated yeasts with malt extract), $\mathrm{N}$ - natural substrate; RC - rearing conditions: $\mathrm{s}$ - cave sediment/ substrate from collecting site, $\mathrm{g}$ - bat guano from collecting site, y - inactivated yeast; EU - eutroglophile, SUB - subtroglophile, TGB - troglobiont, TX - trogloxene; Bb1 - upper hemiedaphobiont, $\mathrm{Bc} 1 \mathrm{a}$ - large euedaphobiont with furca, Bc1b - large euedaphobiont with missing/reduced furca, Bc2a - medium euedaphobiont with furca, $\mathrm{Bc} 2 \mathrm{~b}$ - medium euedaphobiont with missing/reduced furca; EUM- euedaphic microorganisms consumers, EPPM - epigeic plant and microorganisms consumers, EPAM- epigeic animal and microorganisms consumers, HEM- hemiedaphic microorganisms consumers.

Cellulase and trehalase activity was measured by quantifying the rate of glucose production from substrates. For samples, $39 \mu \mathrm{l}$ of homogenate (supernatant) were pipetted into $1.5 \mathrm{ml}$ plastic Eppendorf tubes filled with $39 \mu \mathrm{l}$ of substrate solution: carboxymethyl-cellulose $(0.02 \mathrm{~g} / \mathrm{ml})$ or trehalose $(0.06 \mathrm{~g} / \mathrm{ml})$. Two technical replications for each sample were tested. A homogenate blank containing homogenate and $260 \mu \mathrm{l}$ of trichloracetic acid (TCA) and substrate blanks containing $1 \mathrm{ml}$ of substrate were incubated together with the sample for $24 \mathrm{~h}$ at $37^{\circ} \mathrm{C}$. Before incubation, a drop of toluene was added as a bactericide. After incubation, $260 \mu \mathrm{l}$ of TCA was added to the sample and $39 \mu 1$ of incubated substrate blank solution was added to the homogenate blank and mixed. Samples and blanks were centrifugated at $6,000 \mathrm{rpm} / 7 \mathrm{~min}$., and $50 \mu \mathrm{l}$ of supernatant of samples and blanks were added into separated wells in a microtitration plate filled with $250 \mu \mathrm{l}$ of GLU GOD 250 Lachema reagent to determine the glucose concentration. The microtitration plate was incubated for $20 \mathrm{~min}$ at $37^{\circ} \mathrm{C}$. Then the absorbance was measured at $495 \mathrm{~nm}$ using a microplate reader (Synergy 2, BIO TEK). A glucose solution was used for the calibration.

Chitinase activity (glucosaminidase, chitobiase, endo-chitinase) was measured fluorometrically by quantifying the amount of transformed specific fluorogenic substrates 4-Methylumbelliferyl N-acetyl$\beta$-D-glucosaminide (MUNAGA), 4-Methylumbelliferyl $\mathrm{N}, \mathrm{N}^{-}$-diacetyl- $\beta$-D-chitobioside (MUCHB) and 4-Methylumbelliferyl $\beta-\mathrm{D}-\mathrm{N}, \mathrm{N}^{\prime}, \mathrm{N}^{-\prime}$-triacetylchitotriose, respectively (MUCHT), using the Chitinase Assay Kit, Fluorimetric (Sigma-Aldrich CS1030). For blanks, $100 \mu \mathrm{l}$ of diluted (1:79 by BR buffer) substrate stock solutions of MUNAGA, MUCHB and MUCHT were pipetted onto a black microtitration plate. For samples, $90 \mu 1$ of the same diluted substrate solutions and $10 \mu \mathrm{l}$ of homogenate were used for each of the 3 substrates. The microtitration plate was incubated for $60 \mathrm{~min}$ at $37^{\circ} \mathrm{C}$. After incubation, $200 \mu \mathrm{l}$ of $0.4 \mathrm{M}$ sodium carbonate $\left(\mathrm{Na}_{2} \mathrm{CO}_{3}\right)$ was added into each hollow. Fluorescence was then measured using a microplate reader (Synergy 2, BIOTEK, Excitation = 360/40, Emission = 460/40); 4-Methylumbelliferone solution was used for calibration.

The content of total soluble proteins was determined in each homogenate by adding $100 \mu$ lof the homogenate to $100 \mu \mathrm{l}$ of Bradford reagent (Sigma, B6916) and measuring the absorbance at $595 \mathrm{~nm}$ (Synergy 2, BIOTEK) after incubation at room temperature for 5-45 min. A solution of bovine serum albumin (Sigma, $\mathrm{P} 7656$ ) was used as the protein standard for calibration.

\section{Statistical analyses}

For statistical evaluation of differences in the enzymatic activities among species One-Way ANOVA with HSD post-hoc comparisons were used (software Statistica v6.0). Relationships between body mass and total soluble protein content and between both these parameters and enzymatic activity were tested using multidimensional regression (Statistica v6.0).

The variability of the enzymatic activity was analyzed by applying direct analysis with linear response associated using the CANOCO 5.03 multivariate software package. Constrained partial RDA was performed with species mean body weight as the covariable. We assessed the proportion of the variability explained by different taxonomical categories, morphological traits and environmental 
variables. The forward selection method (FW) showed variables explaining the highest proportion of enzyme variability in a given species. The significance of the environmental variables and categories was specified using the Monte Carlo test with 9999 randomizations.

\section{RESULTS}

The presence of the tested enzymes (trehalase, cellulase and chitinases) from the whole-body homogenates was confirmed in all species under study.

\section{Enzymatic activity in relation to mean body mass and total soluble protein content}

Collembola species differed significantly in their mean body mass (One-way ANOVA, F(7,75) $=62.42$, $\mathrm{p}<0.001$ ), with $P$. spelaeus as the smallest species and $M$. arctica and $P$. janosik as the largest ones (Table 2).

The content of the soluble proteins in one milligram of homogenate increased with decreasing mean body mass of the Collembola groups used for the homogenizations $(\mathrm{r}=0.33$, ANOVA, $\mathrm{F}(1,48)=5.87$, $\mathrm{p}<0.02)$. Considering mean body mass of species, the highest concentration of proteins was measured in the smallest species, $P$. spelaeus, and the lowest in $H$. nitidus. Differences in the content of soluble proteins among species were significant (ANOVA, $\mathrm{F}(7,43)=4.5265, \mathrm{p}<0.001)$. The mean value of this parameter differed significantly in $P$. spelaeus from $H$. nitidus, $F$. candida, $M$. arctica, $O$. rectopapillatus and $P$. janosik (HSD post-hoc comparison, $\mathrm{p}<0.03$, Table 2).

However, the differences in enzymatic activity among species did not simply follow the protein content pattern. The species means of mass-specific enzyme activity of trehalase and chitinase showed increasing trends, with an increasing mean total soluble protein content ( $\mathrm{r}$ from 0.02 to 0.56 ), although linear regression models were not significant (ANOVA, $\mathrm{p}<$ 0.19). Therefore, we preferred to compare enzymatic activities based on protein-specific values. In contrast to other enzymes, the mass-specific activity of cellulase increased insignificantly with a decreasing of the body protein content $(\mathrm{r}=-0.33)$.

The interspecific differences in protein-specific trehalolytic activity were not significant (ANOVA, $\mathrm{F}(7,33)=1.97, \mathrm{p}=0.089)$, with the highest activity observed in $H$. nitidus. Trehalolytic activity in this species differed insignificantly from the lowest activity measured in $M$. arctica and $C$. denticulata (HSD post-hoc comparison, $\mathrm{p}<0.19$, Table 2). The values expressed in mass-specific units showed a similar pattern, with the exception of the overestimated value observed in $P$. spelaeus (Table 2).

Cellulolytic activity showed significant interspecific differences for both mass-specific and proteinspecific values, with the highest activity measured in $M$. arctica (ANOVA, F $(7,32)=4.31, \mathrm{p}=0.0019$ and $\mathrm{F}(7,32)=4.2951, \mathrm{p}=0.0019)$. Activity of the proteinspecific cellulase in $M$. arctica was significantly higher compared to $H$. aequepilosa, $F$. candida, $P$. spelaeus and $P$. janosik (HSD post-hoc comparisons, $\mathrm{p}<0.035$; Table 2).

Chitinolytic activity expressed in protein-specific units displayed significant differences between species. O. rectopapillatus and $H$. aequepilosa showed the highest activity of glucosaminidase compared to other species and significantly higher levels of all chitinolytic enzymes (ANOVA, F(7, 35) $=5.58$, $\mathrm{p}=0.0002$, HSD post-hoc comparison, $\mathrm{p}<0.05)$.

Table 2. Mean body mass, total soluble protein content and enzymatic activities of Collembola species (whole body homogenates). Enzymatic activities expressed as mass-specific $\left(\mathrm{U}^{-1}{ }^{-1}\right)$ and protein-specific $\left(\mathrm{U} . \mathrm{gP}^{-1}\right)$. $\mathrm{U}=$ unit of enzyme activity defined as $\mu \mathrm{Mol} \cdot \mathrm{min}^{-1}$. Means \pm standard errors are presented; small letters indicate significant differences among means at $p=0.05$.

\begin{tabular}{|c|c|c|c|c|c|c|}
\hline \multirow{3}{*}{ Species } & \multirow{3}{*}{$\begin{array}{c}\text { Body mass } \\
\text { pg.ind. }{ }^{-1}\end{array}$} & \multirow{3}{*}{$\begin{array}{c}\text { Proteins } \\
\text { mg.g }{ }^{-1}\end{array}$} & \multicolumn{4}{|c|}{ Enzyme activity } \\
\hline & & & \multicolumn{2}{|c|}{ Trehalase } & \multicolumn{2}{|c|}{ Cellulase } \\
\hline & & & U.g ${ }^{-1}$ & U.gP-1 & U.g ${ }^{-1}$ & U.gP-1 \\
\hline P. spelaeus & $17.98 \pm 0.78 \mathrm{c}$ & $13.84 \pm 2.97 \mathrm{~b}$ & $0.431 \pm 0.364$ & $0.036 \pm 0.022$ & $0.021 \pm 0.011 \mathrm{ab}$ & $0.001 \pm 0.001 \mathrm{~b}$ \\
\hline F. candida & $127.86 \pm 15.84 \mathrm{c}$ & $4.37 \pm 1.41 \mathrm{a}$ & $0.067 \pm 0.023$ & $0.018 \pm 0.009$ & $0.035 \pm 0.010 \mathrm{~b}$ & $0.007 \pm 0.002 \mathrm{~b}$ \\
\hline C. denticulata & $133.91 \pm 13.45 \mathrm{bc}$ & $7.66 \pm 1.67 \mathrm{ab}$ & $0.109 \pm 0.049$ & $0.014 \pm 0.005$ & $0.134 \pm 0.026 \mathrm{a}$ & $0.017 \pm 0.003 a b$ \\
\hline O. rectopapillatus & $134.37 \pm 10.71 \mathrm{bc}$ & $5.22 \pm 0.31 \mathrm{a}$ & $0.282 \pm 0.172$ & $0.050 \pm 0.028$ & $0.098 \pm 0.018 \mathrm{ab}$ & $0.019 \pm 0.004 \mathrm{ab}$ \\
\hline H. aequepilosa & $127.28 \pm 6.15 \mathrm{bc}$ & $7.43 \pm 1.48 \mathrm{ab}$ & $0.186 \pm 0.060$ & $0.031 \pm 0.015$ & $0.061 \pm 0.015 \mathrm{ab}$ & $0.008 \pm 0.002 \mathrm{~b}$ \\
\hline H. nitidus & $253.95 \pm 32.46 \mathrm{~b}$ & $4.00 \pm 0.43 \mathrm{a}$ & $0.292 \pm 0.056$ & $0.081 \pm 0.012$ & $0.081 \pm 0.026 \mathrm{ab}$ & $0.020 \pm 0.006 \mathrm{ab}$ \\
\hline P. janosik & $590.58 \pm 105.97 \mathrm{a}$ & $4.54 \pm 0.53 \mathrm{a}$ & $0.255 \pm 0.087$ & $0.064 \pm 0.021$ & $0.041 \pm 0.024 \mathrm{~b}$ & $0.009 \pm 0.005 \mathrm{~b}$ \\
\hline \multirow[t]{4}{*}{ M. arctica } & $620.27 \pm 12.59 \mathrm{a}$ & $4.77 \pm 0.89 \mathrm{a}$ & $0.065 \pm 0.002$ & $0.014 \pm 0.001$ & $0.131 \pm 0.013 \mathrm{a}$ & $0.027 \pm 0.003 \mathrm{a}$ \\
\hline & \multicolumn{6}{|c|}{ Enzyme activity } \\
\hline & \multicolumn{2}{|c|}{ Glucosaminidase } & \multicolumn{2}{|c|}{ Chitobiase } & \multicolumn{2}{|c|}{ Endochitinase } \\
\hline & U.g ${ }^{-1}$ & U.gP'-1 & U.g ${ }^{-1}$ & U.gP'-1 & U.g ${ }^{-1}$ & U.gP-1 \\
\hline P. spelaeus & $0.955 \pm 0.921$ & $0.062 \pm 0.055 \mathrm{~b}$ & $0.425 \pm 0.421$ & $0.026 \pm 0.026 \mathrm{ab}$ & $0.218 \pm 0.214 \mathrm{~b}$ & $0.014 \pm 0.013 \mathrm{~b}$ \\
\hline F. candida & $0.156 \pm 0.118$ & $0.036 \pm 0.027 \mathrm{~b}$ & $0.080 \pm 0.024$ & $0.020 \pm 0.007 \mathrm{~b}$ & $0.077 \pm 0.021 \mathrm{~b}$ & $0.019 \pm 0.006 \mathrm{~b}$ \\
\hline C. denticulatus & $9.712 \pm 6.092$ & $0.087 \pm 0.018 \mathrm{~b}$ & $0.212 \pm 0.056$ & $0.032 \pm 0.009 \mathrm{~b}$ & $0.153 \pm 0.034 \mathrm{~b}$ & $0.023 \pm 0.005 \mathrm{~b}$ \\
\hline O. rectopapillatus & $2.035 \pm 0.343$ & $0.414 \pm 0.086 \mathrm{a}$ & $0.581 \pm 0.146$ & $0.117 \pm 0.030 \mathrm{a}$ & $0.863 \pm 0.183 \mathrm{a}$ & $0.177 \pm 0.046 \mathrm{a}$ \\
\hline H. aequepilosa & $1.840 \pm 0.266$ & $0.273 \pm 0.071 \mathrm{ab}$ & $0.509 \pm 0.149$ & $0.071 \pm 0.022 \mathrm{ab}$ & $0.388 \pm 0.152 \mathrm{ab}$ & $0.054 \pm 0.024 \mathrm{~b}$ \\
\hline H. nitidus & $0.644 \pm 0.101$ & $0.161 \pm 0.023 \mathrm{~b}$ & $0.144 \pm 0.026$ & $0.035 \pm 0.006 \mathrm{~b}$ & $0.148 \pm 0.030 \mathrm{~b}$ & $0.036 \pm 0.006 \mathrm{~b}$ \\
\hline P. janosik & $0.766 \pm 0.279$ & $0.183 \pm 0.060 \mathrm{~b}$ & $0.180 \pm 0.083$ & $0.040 \pm 0.018 \mathrm{~b}$ & $0.144 \pm 0.062 \mathrm{~b}$ & $0.033 \pm 0.013 \mathrm{~b}$ \\
\hline M. arctica & $0.602 \pm 0.176$ & $0.126 \pm 0.037 \mathrm{~b}$ & $0.088 \pm 0.027$ & $0.018 \pm 0.006 \mathrm{~b}$ & $0.078 \pm 0.026 \mathrm{~b}$ & $0.016 \pm 0.005 \mathrm{~b}$ \\
\hline
\end{tabular}


The activity of chitobiases in $O$. rectopapillatus was higher than in other species, with an exception of $H$. aequepilosa and $P$. spelaeus (ANOVA, F(7, $35)=3.77, \mathrm{p}=0.0038$, HSD post-hoc comparison, $\mathrm{p}<0.05)$, while the endochitinase activity in this species was higher than in all other species (ANOVA, $\mathrm{F}(7,35)=7.0734, \mathrm{p}=0.00003$, HSD post-hoc comparison, $\mathrm{p}<0.002)$.

\section{Enzymatic activity and Collembola categories}

Considering the taxonomical categories, the highest proportion of enzymatic variability was explained at the species level (Table 3). The degree of association with caves (cave guilds) was more important for the collembolan enzymatic equipment than feeding guilds or life forms (Table 4).

Direct RDA ordination (Fig. 1) placed F. candida and $P$. spelaeus in the same quadrant of the ordination space, contrary to $M$. arctica and $O$. rectopapillatus. All populations of $P$. janosik had similar enzymatic

Table 3. Enzymatic variability (partial RDA) explained by systematic categories. The significance of the first canonical axis was tested. F - Fisher statistics, P - significance level, ND - not determined.

\begin{tabular}{|l|c|c|c|}
\hline \multicolumn{1}{|c|}{ Categories } & $\begin{array}{c}\text { explained } \\
\text { variability } \%\end{array}$ & F & P \\
\hline Order & 4.6 & ND & \\
\hline Family & 19.3 & 9.6 & 0.025 \\
\hline Species & 53.0 & 26.0 & 0.001 \\
\hline Order + Family + Species & 53.8 & 18.6 & 0.002 \\
\hline
\end{tabular}

Table 4. Enzymatic variability (partial RDA) explained by ecological categories. The significance of the first canonical axis was tested. F - Fisher statistics, P - significance level.

\begin{tabular}{|l|c|c|c|}
\hline \multicolumn{1}{|c|}{ Categories } & $\begin{array}{c}\text { explained } \\
\text { variability \% }\end{array}$ & F & P \\
\hline Feeding guilds & 25.1 & 10.2 & 0.006 \\
\hline Life forms & 14.5 & 5.7 & 0.009 \\
\hline Cave forms & 35.7 & 14.9 & 0.001 \\
\hline
\end{tabular}

equipment, but one with distinctly higher chitinase activity.

Among categorical variables, the largest variability was explained by cave affinity (cave guilds), less by life forms and feeding guilds (Table 5). Functional traits were not significant, but body length was evaluated as the most important. The activity of digestive enzymes explained by cave guilds showed an increasing trend in cellulolytic activity from troglobionts to trogloxenes (Fig. 2A). However, all the categories partially overlapped, and subtroglophiles seemed to be the most diverse in enzymatic activity (Fig. 2B).

Enzymatic activity within the feeding guilds (Fig. 3A) indicated an increasing trend of cellulase activity from "epigeic animal and microorganism consumers" (EPAM) to "epigeic plant and microorganism consumers" (EPPM). Chitinolytic activity decreased from "euedaphic microorganism consumers" (EUM) to "hemiedaphic microorganism consumers" (HEM). But the more detailed view, including the variability within guilds, showed that EUM represented the most variable group, while variability within EPPM, HEM and EPAM was smaller (Fig. 3B). Enzymatic activity explained by life forms showed a pattern similar to that of the feeding guilds (Fig. 4). Euedaphobionts (Bc) showed higher variability in contrast to hemiedaphobionts (Bb, identical to EPAM guild).

\section{DISCUSSION}

\section{Enzymatic equipment in cave-dwelling Collembola}

The presence or absence of certain enzymes associated with digestion can reflect the ability of animals to utilize various food sources. The proportions of digestive enzymes may indicate what amount of different food sources may be potentially digested by the animal; however, the potential and actual diet may differ. Quantitative proportions of

Table 5. Enzymatic variability explained by categorical variables and functional traits; variables that explain the highest proportion of enzymatic variability using the forward selection method (FW) are marked. F - Fisher statistics, $P-$ significance level, P (adj) - significance with Holm correction P-values in bold are significant. Significance based on Monte Carlo tests with 9999 randomizations. Covariable: body weight; analysis: interactive forward selection with covariate.

\begin{tabular}{|c|c|c|c|c|c|}
\hline & Explained variability \% & $\mathbf{F}$ & $\mathbf{P}$ & $\mathbf{P}(\mathbf{a d j})$ & FW selection \\
\hline Cave dwelling - trogloxene & 16.3 & 3.9 & 0.019 & 0.235 & $\checkmark$ \\
\hline Cave dwelling - subtroglophile & 54.8 & 16.6 & 0.000 & 0.001 & $\checkmark$ \\
\hline Cave dwelling - eutroglophile & 16.9 & 4.1 & 0.014 & 0.183 & \\
\hline Cave dwelling - troglobiotic & 10.6 & 2.5 & 0.070 & 0.630 & \\
\hline Life form $-\mathrm{Bc} 1 \mathrm{a}$ & 5.6 & 1.3 & 0.251 & 1 & \\
\hline Life form $-\mathrm{Bc} 1 \mathrm{~b}$ & 28.3 & 7.3 & 0.001 & 0.025 & \\
\hline Life form $-\mathrm{Bc} 2 \mathrm{a}$ & 8.8 & 2.0 & 0.098 & 0.778 & \\
\hline Life form $-\mathrm{Bc} 2 \mathrm{~b}$ & 8.4 & 1.9 & 0.110 & 0.778 & \\
\hline Feeding guilds - eum & 27.4 & 5.8 & 0.002 & 0.039 & \\
\hline \multicolumn{6}{|l|}{ Functional traits } \\
\hline Body length & 13.7 & 3.3 & 0.035 & 0.357 & \\
\hline Proteins (Bradford) & 4.0 & 0.9 & 0.389 & 1 & \\
\hline Eyes & 2.1 & 0.5 & 0.701 & 1 & \\
\hline
\end{tabular}




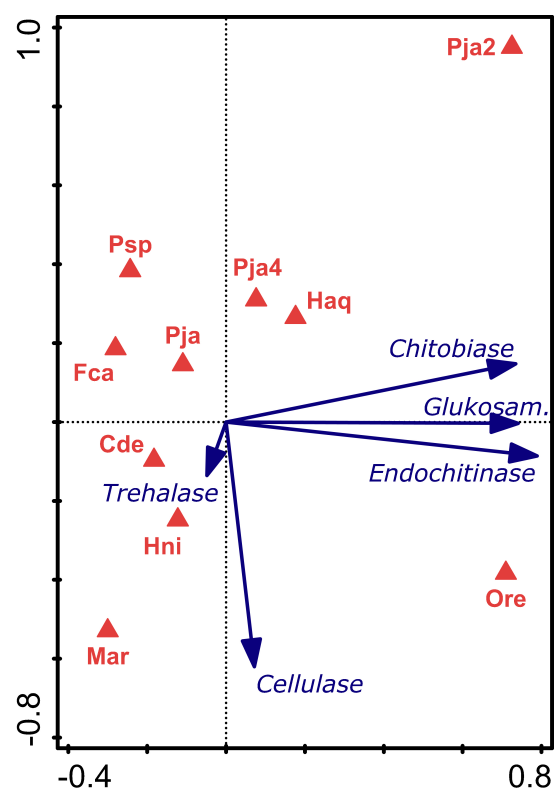

Fig. 1. Variability of the protein-specific enzymatic activities of digestive enzymes in tested Collembola explained by differences among species. Red triangles indicate centroids. Direct RDA ordination. Cde - Ceratophysella denticulata; Fca - Folsomia candida; Hni - Heteromurus nitidus; Haq - Hypogastrura aequepilosa; Mar - Megaphorura arctica; Ore - Orthonychiurus rectopapillatus; Pja - Protaphorura janosik; Psp - Pseudacherontides spelaeus.

enzyme activity may respond to the actual food more sensitively than qualitative ones.

In the present study, the species collected in caves were examined to reveal their enzymatic equipment in relation to specific conditions of subterranean habitats. Urbášek \& Rusek (1994) found only slight differences in the enzymatic activity between Collembola life forms. Similarly, we confirmed the presence of all tested enzymes in body homogenates of the species involved in this study. The enzymatic equipment corresponded to herbo-fungivorous grazers, the most prevalent collembolan feeding guild (Berg et al., 2004). Although all species examined were qualitatively uniform in digestive enzymes, the activities of enzymes exploiting the same substrate quantitatively differed between species. The quantitative differences of enzymatic activities did not simply follow concentrations of soluble proteins; thus, an effect of the genetically fixed infraspecific proportions of certain digestive enzymes is indicated. This may reflect food specialization determined by evolutionary adaptation or non-genetic regulation of synthesis or activation of different enzymes.

We observed significant differences in cellulolytic and chitinolytic activity between the cave species, confirming the key importance of these enzymes in the indication of their feeding habits. The majority of species displayed very low cellulolytic activity compared to other enzymes. The increasing trend of cellulase activity towards trogloxenes and subtroglophiles confirmed our hypothesis. Thus, the degradation of fresh plants and wood is nonrelevant for collembolans occupying a deeper cave environment, which is primarily oligotrophic (Culver $\&$ Pipan, 2009). Along with cellulase produced in the midgut or by salivary glands, some insects contain cellulases released by symbiotic bacteria (Fisher et al., 2013) or may have horizontally transferred genes for cellulases involved in carbohydrate metabolism and cellulose degradation (Faddeeva-Vakhrusheva et al., 2016). In general, it is difficult to specify whether the enzymes responsible for the breakdown of food items originate from the animal itself or are excreted in the alimentary tract by the microflora when deriving the enzymatic activity from whole-body homogenates (Berg et al., 2004; Fisher et al., 2013). An endogenous cellulolytic protein has been confirmed in only one collembolan species, Cryptopygus antarcticus (Song et al., 2017).

Rearing conditions can influence the enzymatic equipment as well, especially quantitatively. Despite the fact that most of the species examined in the present study came from a laboratory culture feeding with yeast, significant interspecific differences were observed. This suggests that these differences are not associated with the current physiological responses in
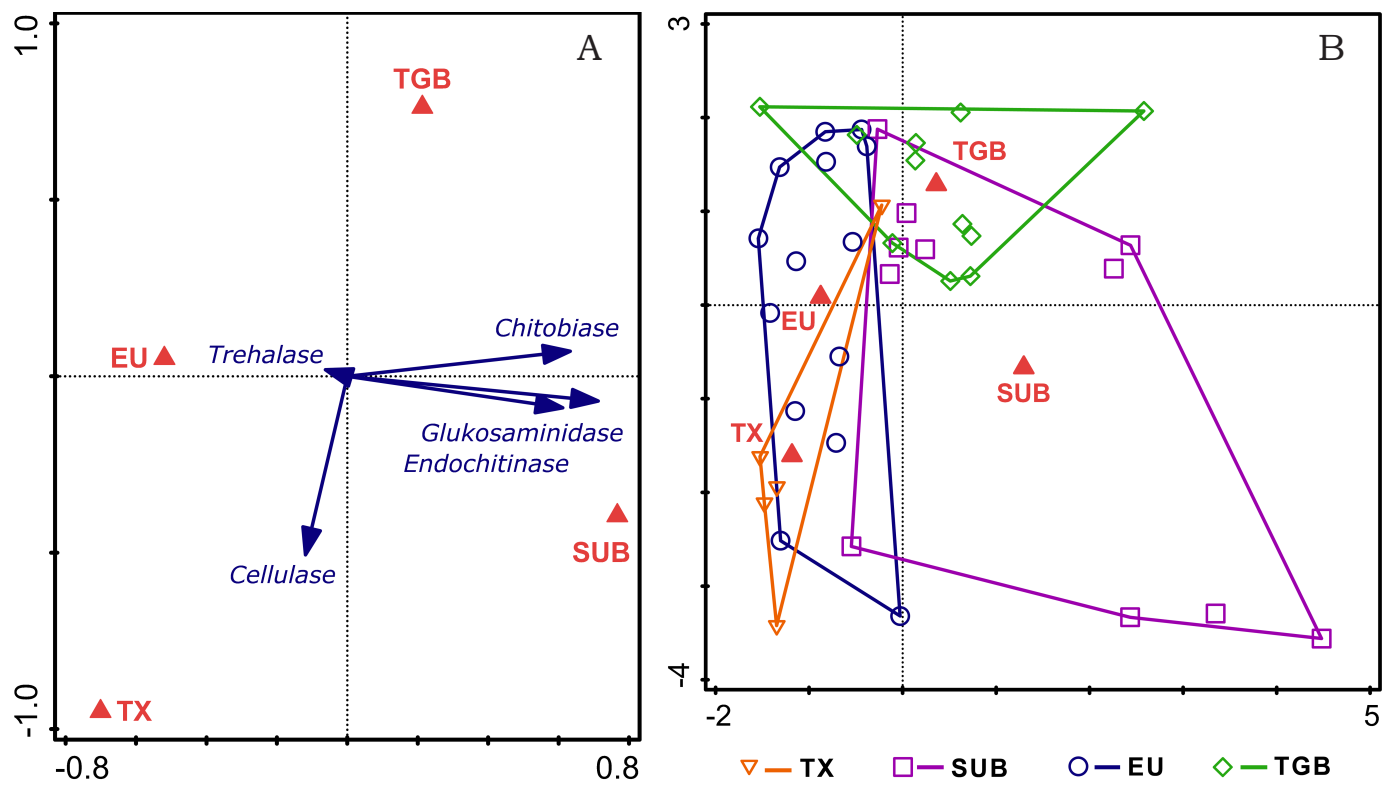

Fig. 2. Enzymatic activity in Collembola explained by cave guilds $(A)$ and variability within cave guilds (B). Red triangles indicate centroids. Direct RDA ordination. Abbreviations: EU - eutroglophile; SUB - sub-troglophile; TGB - troglobiont; TX - trogloxene. 

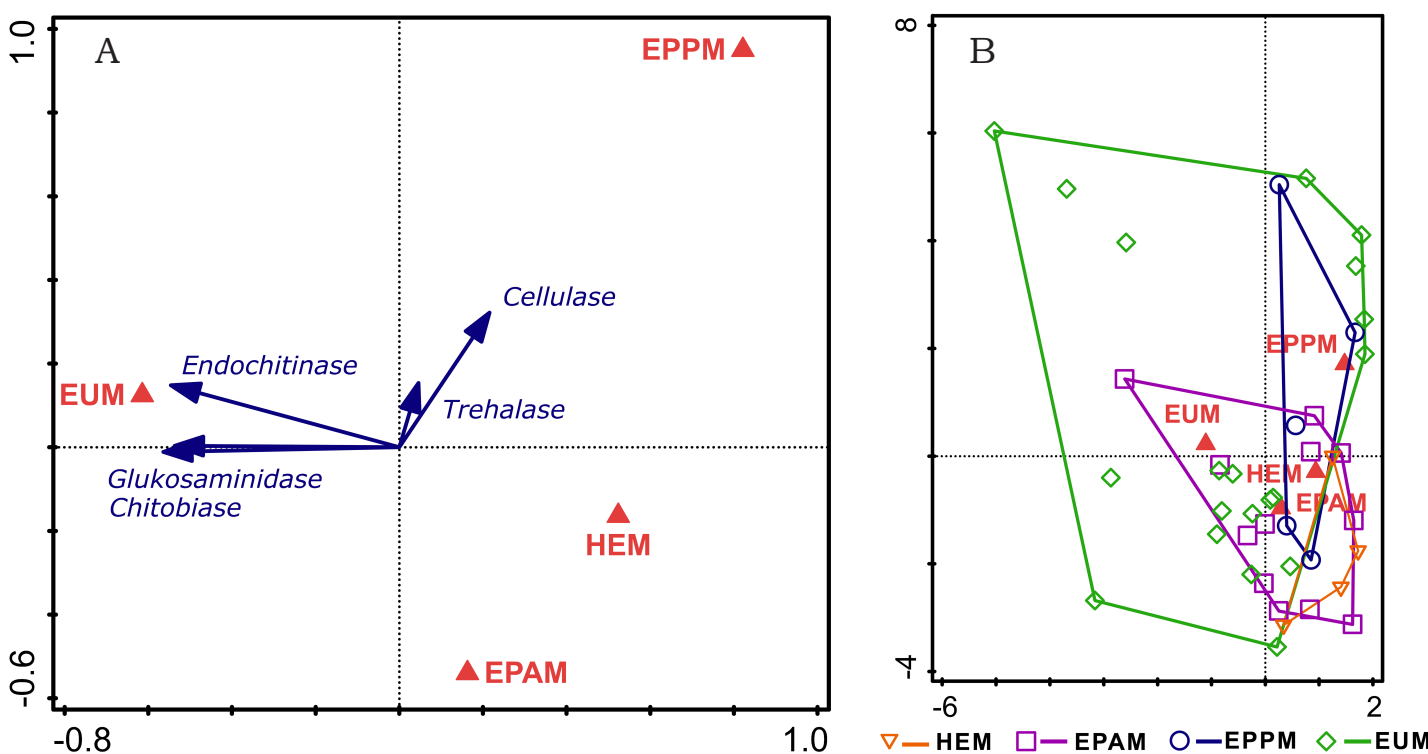

Fig. 3. Enzymatic activity of Collembola explained by feeding guilds (A) and variability within particular categories (B). Red triangles indicate centroids. Direct RDA ordination. Abbreviations: EUM - euedaphic microorganisms consumers; EPPM - epigeic plant and microorganisms consumers; EPAM - epigeic animal and microorganisms consumers; HEM - hemiedaphic microorganisms consumers.

relation to artificial food but reflect the species-specific enzymatic equipment. Two natural populations of $P$. janosik did not display any differences from one another in enzymatic activity. In contrast, a distinct pattern in the activity of digestive enzymes was found in comparing natural populations with a long-term laboratory culture reared on substrate from the sampling locality and feeding on yeast. Thus, the enzymatic equipment of the laboratory population characterized by high activity of chitinases probably reflects the artificial yeast-enriched diet. However, only one sample from the culture was available; thus, the increasing trend towards chitinolytic activity in the population feeding on yeast could not be statistically supported. The influence of the abovementioned factors on enzymatic equipment of the cave collembolans requires further study. Unfortunately,

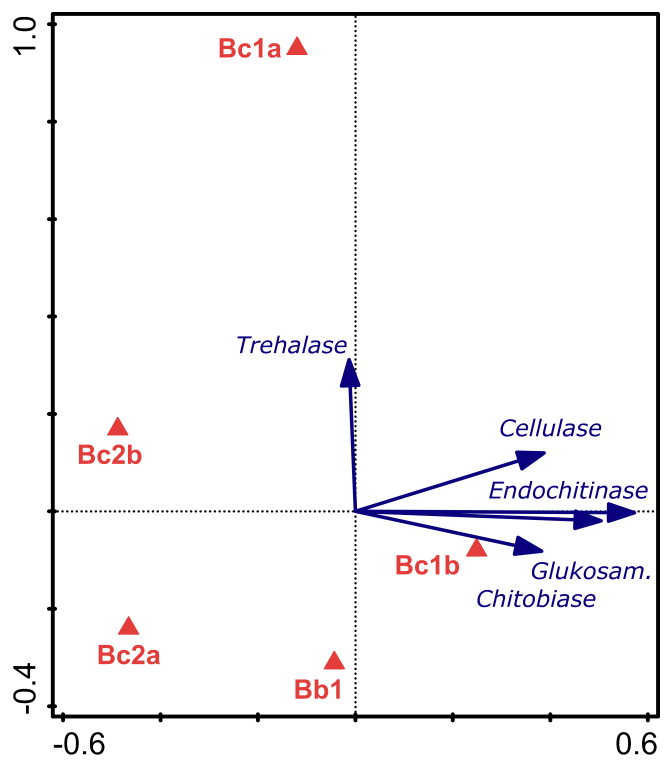

Fig. 4. Enzyme activity of Collembola explained by life forms. Red triangles indicate centroids. Direct RDA ordination. Abbreviations: $\mathrm{Bb} 1$ - upper hemiedaphobiont; Bc1a - large euedaphobiont with furca; Bc1b - large euedaphobiont with missing/reduced furca; $\mathrm{Bc2a}$ - medium euedaphobiont with furca; Bc2b - medium euedaphobiont with missing/reduced furca. the difficult access to subterranean environments and mostly dispersed distribution of Collembola specimens in caves make the collection of the material for study of digestive enzymes highly demanding.

\section{Enzymatic activity of Collembola and affinity to cave environment (cave guild)}

Trogloxene species $M$. arctica is classified as a euedaphobiotic life form (Rusek, 2007) and an epigeic plant and microorganisms consumer (Potapovet al., 2016). We observed high cellulolytic activity and very low chitinolytic activity in this trogloxene species, which is in accordance with findings of Hodkinson et al. (1994) that it feeds predominantly on living and dead bryophytes, detritus and algal cells.

As to the troglophiles, both subtroglophile species, $O$. rectopapillatus and $H$. aequepilosa, differed in the proportion of enzyme activities, indicating variability of feeding preferences inside this cave guild. Generally, subtroglophiles were established as secondary decomposers based on analyses of stable isotopes (Chahartaghia et al., 2005), grazing on saprophytic, endomycorrhizal and ectomycorrhizal fungi. This corresponds to the relatively high activity of chitinases in $O$. rectopapillatus. On the other hand, we registered low activity of all tested enzymes in $H$. aequepilosa, which is classified as an animal and microorganisms consumer (Potapov et al., 2016). Subtroglophiles appear to be food generalists rather than specialists (Maraun et al., 2003). This is likely the case of the guild occupying the cave entrances, the habitat enriched by heterogenous dead organic material colonized with subtroglophiles.

The category "eutroglophile" is represented in our study by $F$. candida and $H$. nitidus, both classified also as hemiedaphic microorganism consumers, and C. denticulata, also classified as an epigeic plant and animal consumer and fungal feeding secondary decomposer (Ruess et al., 2007; Chahartaghia et al., 2005; Potapov et al., 2016). Such variability in feeding preferences in this cave guild is indicated by 
variable mouthparts morphology and trophic niche preferences (Malcicka et al., 2016; Potapov et al., 2016) and results in significant differences in the enzymatic equipment shown in the recent study.

Troglobionts $P$. spelaeus and $P$. janosik differed in enzymatic activity, which reflects their different food specialization associated with microhabitat selection. $P$. spelaeus is a strict guanobiont, while $P$. janosik occurs in a wider spectrum of cave microhabitats, including cave sediment and rotten wood. Generally, there is a difference in guano-colonizing organisms preferring guano deposits of different age. Raw (acid) guano is colonized by microfungi, while in older guano bacteria dominate (Nováková et al., 2005). The lower chitinolytic and higher trehalolytic activity in $P$. spelaeus suggests its specialized feeding on the cell content of metabolically active fungal hyphae (Berg et al., 2004).

\section{Enzymatic activity in cave-adapted fauna in evolutionary approach}

The edaphic lifestyle was proposed as the evolutionary ancestral state of Collembola (D`Haese, 2002). Considering the evolution of cave-adapted fauna from preadapted relatives (Holsinger, 2000) and the lack of primary production in caves, we assumed a shift of enzymatic activity from cellulases in edaphic forms towards chitinases in obligate cave forms. On the other hand, incidental and relatively poor food sources in caves may suggest the evolutionary pressure to maintain the ability to utilize various sources of energy. It is also conceivable that diversification of species generally leads to the colonization of various food niches during their evolution and is associated with more rapid changes in enzyme activities compared to body or mouthparts morphology. In the present study, higher variability was observed at the species level compared to families. This suggests that affiliation to higher taxonomical categories, and thus similar mouthparts morphology as well as general body plan, does not fully designate species to an equal ecological role. This is supported by the different enzymatic activities found in species within the same family. The above-mentioned disproportions between enzymatic activity and available categorizations point to the existence of food-specialists, regardless of the life-form or cave guild.

Enzymatic activity as an adaptive feature in obligate (troglobiotic) cave Collembola is still poorly known. It is necessary to examine a wider spectrum of such species and several populations within each caveadapted form to investigate interspecific differences in enzymatic equipment as well as differences within the same species. Moreover, the molecular approach, especially identification of genes responsible for production or activation of particular enzymes, could explain the mechanisms leading to different physiology of digestion in subterranean Collembola.

\section{CONCLUSIONS}

Activity of all tested enzymes was confirmed across all cave guilds, probably as a result of the evolutionary pressure to maintain the ability to utilize various food sources. The quantitative differences of enzymatic activities did not simply follow concentrations of soluble proteins; thus, an effect of the genetically fixed infraspecific proportions of certain digestive enzymes is indicated. Cellulolytic and chitinolytic activity showed a key role in the indication of species feeding habits. Different enzymatic activity was found within the same family, supporting the statement that the ecological role of the species is not determined by its taxonomical category. Quantitative interspecific differences were not associated with the current physiological responses in relation to artificial food, thus reflecting the species-specific enzymatic equipment. The study confirmed our hypothesis that there is a shift of enzymatic activity from cellulases in edaphic forms towards chitinases in obligate cave forms of Collembola

\section{ACKNOWLEDGEMENTS}

The study was supported by the grants VEGA1/0346/18, VVGS-2014-224 and GACR 1720839S. The participation of O. Vošta in the study was supported by the program Open Science II, within the Operational Programme Education for Competitiveness, Support Area 2.3, co-financed from the state budget of the Czech Republic and the European Social Fund (project No. CZ.1.07/2.3.00/09.0034). Part of the study was supported by the Ministry of Education, Youth and Sports of the Czech Republic - MEYS (projects LM2015075, EF16_013/0001782). We are grateful to Dr. Peter Čuchta for identification of some Collembola material and Dr. CristianMihai Munteanu for his help with the collecting of Collembola specimens in Romania. David McLean is acknowledged for the linguistic corrections of the manuscript draft.

\section{REFERENCES}

Arakane Y. \& Muthukrishnan S., 2010 - Insect chitinase and chitinase-like proteins. Cellular and Molecular Life Sciences, 67: 201-216.

https://doi.org/10.1007/s00018-009-0161-9

Berg M.P., Stoffer M. \& van den Heuvel, H.H., 2004 - Feeding guilds in Collembola based on digestive enzymes. Pedobiologia, 48: 589-601.

https://doi.org/10.1016/j.pedobi.2004.07.006

Camassa M.M., 2004 - Food resources. In: Gunn J. (Ed.), Encyclopaedia of caves and karst science. Fitzroy Dearborn, New York, p. 755-761.

Castaño-Meneses G., Palacios-Vargas J.G. \& CutzPool L.Q., 2004 - Feeding habits of Collembola and their ecological niche. Anales del Instituto de Biologia, Universidad Nacional Autónoma de México, Serie Zoología, 75 (1): 135-142.

Culver D.C. \& Pipan T., 2009 - The biology of caves and other subterranean habitats. New York: Oxford University Press Inc., 254 p.

D'Haese C.A., 2002 - Were the first springtails semiaquatic? A phylogenetic approach by means of $28 \mathrm{~S}$ rDNA and optimization alignment. Proceedings of the Royal Society of London. Series B, 269: 1143-1151. https://doi.org/10.1098/rspb.2002.1981 
Endlweber K., Ruess L. \& Scheu S., 2009 - Collembola switch diet in presence of plant roots thereby functioning as herbivores. Soil Biology \& Biochemistry, 41: 11511154. https://doi.org/10.1016/j.soilbio.2009.02.022

Faddeeva-Vakhrusheva A., Derks M.F.L., Anvar S.Y., Agamennone V., Suring W., Smit S., van Straalen N.M. \& Roelofs D. 2016 - Gene family evolution reflects adaptation to soil environmental stressors in the genome of the Collembolan Orchesella cincta. Genome Biology and Evolution, 8 (7): 2106-2117. https://doi.org/10.1093/gbe/evw134

Fiera C., 2014 - Detection of food in the gut content of Heteromurus nitidus (Hexapoda: Collembola) by DNA/ PCR-based molecular analysis. North-western Journal of Zoology, 10 (1): 67-73.

http://biozoojournals.ro/nwjz/content/v10n1/ nwjz_131106_Fiera.pdf

Fisher R., Ostafe R. \& Twyman R.M., 2013 - Cellulases from Insects. Advances in Biochemical Engineering/ Biotechnology, 136: 51-64.

https://doi.org/10.1007/10 2013206

Hishi T., Hyodo F., Saitoh S. \& Takeda H., 2007 - The feeding habits of Collembola along decomposition gradients usingstable carbon and nitrogen isotope analyses. Soil Biology \& Biochemistry, 39: 1820-1823. https://doi.org/10.1016/j.soilbio.2007.01.028

Hodkinson I.D., Coulson S., Webb N.R., Block W., Strathdee A.T. \& Bale J.S., 1994 - Feeding studies on Onychiurus arcticus (Tullberg) (Collembola: Onychiuridae) on West Spitsbergen. Polar Biology, 14: 17-19.

https://doi.org/10.1007/BF00240267

Holsinger J.R., 2000 - Ecological derivation, colonization, and speciation. In: Wilkens H., Culver D.C. \& Humphreys W.F. (Eds.), Ecosystems of the world 30. Subterranean ecosystems. Elsevier, Amsterdam, p. 399-416.

Kováč L., Elhottová D., Mock A., Nováková A., Krištůfek V., Chroňáková A., Lukešová, A., Mulec J., Košel V., Papáč V., Luptáčik P., Uhrin M., Višňovská Z., Hudec I., Gaál L. \& Bella P., 2014 - The cave biota of Slovakia. Speleologia Slovaca 5. Liptovský Mikuláš: State Nature Conservancy SR, Slovak Caves Administration, 191 p.

Chahartaghia M., Langelb R., Scheu S., \& Ruess L., 2005 - Feeding guilds in Collembola based on nitrogen stable isotope ratios. Soil Biology \& Biochemistry, 37: 1718-1725.

https://doi.org/10.1016/j.soilbio.2005.02.006

Malcicka M., Berg M. \& Ellers J., 2017 -Ecomorphological adaptations in Collembola in relation to feeding strategies and microhabitat. European Journal of Soil Biology, 78: 82-91.

https://doi.org/10.1016/j.ejsobi.2016.12.004

Maraun M., Martens H., Migge S., Theenhaus A. \& Scheu S., 2003 - Adding to 'the enigma of soil animal diversity: Fungal feeders and saprophagous soil invertebrates prefer similar food substrates. European Journal of Soil Biology, 39: 85-95. https://doi.org/10.1016/S1164-5563(03)00006-2

Merzendorfer H. \& Zimoch L., 2003 - Chitin metabolism in insects: structure, function and regulation of chitin synthases and chitinases. Journal of Experimental Biology, 206: 4393-4412.

https://doi.org/10.1242/jeb.00709
Nováková A., Elhottová D., Krištůfek V., Lukešová A., Hill P., Kovač L., Mock A. \& Luptáčik P., 2005 - Feeding sources of invertebrates in Ardovská Cave and Domica Cave systems - preliminary results. In: Tajovský K., Schlaghamersky J. \& Pižl V. (Eds.), Contributions to soil zoology in Central Europe I. Institute of Soil Biology AS ČR, České Budějovice, p. 107-112.

Ponge J.F., 2000 - Vertical distribution of Collembola (Hexapoda) and their food resources in organic horizons of beech forests. Biology and Fertility of Soils, 32: 508522. https://doi.org/10.1007/s003740000285

Potapov A.A, Semenina E.E., Korotkevich A.Yu., Kuznetsova N.A. \& Tiunov A.V., 2016 - Connecting taxonomy and ecology: Trophic niches of collembolans as related to taxonomic identity and life forms. Soil Biology \& Biochemistry, 101: 20-31.

https://doi.org/10.1016/j.soilbio.2016.07.002

Ruess L. Häggblom M.M., Langel R. \& Scheu S., 2004 - Nitrogen isotope ratios and fatty acid composition as indicators of animal diets in belowground systems. Oecologia, 139: 336-46.

https://doi.org/10.1007/s00442-004-1514-6

Ruess L., Schütz K., Migge-Kleian S., Häggblom M.M., Kandeler E. \& Scheu S., 2007 - Lipid composition of Collembola and their food resources in deciduous forest stands-Implications for feeding strategies. Soil Biology \& Biochemistry, 39: 1990-2000.

https://doi.org/10.1016/j.soilbio.2007.03.002

Rusek J., 1998 - Biodiversity of Collembola and their functional role in the ecosystem. Biodiversity and Conservation, 7: 1207-1219. https://doi.org/10.1023/A:1008887817883

Rusek J., 2007 - A new classification of Collembola and Protura life forms. In: Contributions to soil zoology in central Europe II. ISB BC ASCR. České Budějovice, p. $109-115$.

Siepel H. \& De Ruiter-Dijkman E.M., 1993 - Feeding guilds of oribatid mites based on their carbohydrase activities. Soil Biology \& Biochemistry, 25: 1491-1497. https://doi.org/10.1016/0038-0717(93)90004-U

Sinclair B.J. \& Sjursen H., 2001 - Cold tolerance of the Antarctic springtail Gomphiocephalus hodgsoni (Collembola, Hypogastruridae). Antarctic Science, 13 (3): 271-279.

https://doi.org/10.1017/S0954102001000384

Song J.M., Hong S.K., An Y.J., Kang M.H., Hong K.H., Lee Y.H. \& Cha S.S., 2017 - Genetic and structural characterization of a thermo-tolerant, cold-active, and acidic endo-beta-1,4-glucanase from Antarctic Springtail, Cryptopygus antarcticus. Journal of Agricultural and Food Chemistry, 65: 1630-1640.

https://doi.org/10.1021/acs.jafc.6b05037

Thompson S.N., 2003 - Trehalose - The insect 'blood' sugar. Advances in Insect Physiology, 31: 205-285. https://doi.org/10.1016/S0065-2806(03)31004-5

Urbášek F. \& Rusek J.,1994 - Activity of digestive enzymes in seven species of Collembola (Insecta: Entognatha). Pedobiologia, 38: 400-406.

Zinkler D., 1971 - Carbohydrasen streubewohnender Collembolen und Oribatiden. Comptes Rendus IV. Colloque Faune du Sol, p. 329-334. 